Article

\title{
A Humboldtian Critique of the University of the Philippines as the Flagship of Philippine Higher Education (Part I)
}

\section{F.P.A. Demeterio III Roland Theuas DS. Pada}

\begin{abstract}
For the Philippines to benefit from the ASEAN integration and globalization, in general, it must be able to mold highly educated citizens who can proactively engage themselves with the national, regional, and international knowledge economies. ${ }^{1}$ The Philippines has nine research universities that presumably lead its approximately 2,500 higher educational institutions in molding these needed citizens. These nine research universities are the eight autonomous constituent units of the University of the Philippines and De La Salle University. The idea of the modern research university was invented more than 200 years ago in Berlin by the philosopher, linguist, humanist, and statesman Wilhelm von Humboldt (1767-1835). Around 1850, American educational leaders started to appropriate Humboldt's ideas to establish the American research universities. As the University of the Philippines is an American creation and at the same time the flagship institution of Philippine higher education, this paper used the Humboldtian philosophy of education, as well as its American rendition, in looking at the soundness of this university's claim to be a research university. To attain this goal this paper has three substantive sections: 1) a discussion on Humboldt's philosophy of education, 2) a discussion on the American translation of Humboldt's philosophy of education, 3) a critique of the foundational principles of the University of the Philippines as a research university.
\end{abstract}

Keywords: Wilhelm von Humboldt, Humboldtian research university, American research university, Philippine higher education

${ }^{1}$ Philip G. Altbach, "The Past, Present, and Future of the Research University," in The Road to Academic Excellence: The Making of World-Class Research Universities, ed. by Philip G. Altbach and Jamil Salmi (Washington, D.C.: The World Bank, 2011), 11.

(C) 2018 F.P.A. Demeterio III and Roland Theuas DS. Pada

https://www.kritike.org/journal/issue 23/demeterio\&pada december2018.pdf

ISSN 1908-7330

$(\mathrm{Cc}) \overline{\mathrm{BY}-\mathrm{NC}-\mathrm{ND}}$ 


\section{A HUMBOLDTIAN CRITIQUE}

7 he idea of the modern research university was invented more than 200 years ago in Berlin, the capital at that time of the Kingdom of Prussia, by the German philosopher, linguist, humanist, and statesman Wilhelm von Humboldt (1767-1835). Around 1850, American educational leaders started to appropriate Humboldt's ideas to establish the American research universities. ${ }^{2}$ UP was founded by the Philippine Legislative Assembly, under the American colonial government in 1908. In 1972, the whole University of the Philippines was reorganized into a system, which eventually had eight constituent autonomous units, namely: 1) University of the Philippines Los Baños, 1972; 2) University of the Philippines Manila, 1979; 3) University of the Philippines Visayas, 1979;4) University of the Philippines Diliman, 1985; 5) University of the Philippines Open University, 1995; 6) University of the Philippines Mindanao, 1995; 7) University of the Philippine Baguio, 2002; and 8) University of the Philippines Cebu, 2010. UP is the flagship university of the country per R.A. 9500.

\section{Introduction}

As UP is an American creation and at the same time the flagship institution of Philippine higher education, this paper used Humboldt's philosophy of education as well as its American rendition in looking at the soundness of this university's claim as a research university. To attain this goal this paper has three substantive sections: 1) a discussion on Humboldt's philosophy of education, 2) a discussion on the American rendition of Humboldt's philosophy of education, and 3) a critique of the foundational principles of UP as a research university.

The first section was formulated by mainly using Humboldt's short essay, titled "On the Internal and External Organization of the Higher Scientific Institutions in Berlin," as well as some English language commentaries on the Humboldtian educational revolution. The second section was written by using English language accounts of how Humboldt's ideas reached the United States of America and how these were eventually instrumental to the development of the so-called American research university. The third section was done by articulating it into four sub-sections representing four periods of UP: 1) the university under the American colonization (1908-1946), 2) the university after the liberation (1946-1972), 3) the university as a system (1972-2008), and 4) the university's transition to a research university (2008-present). Key documents from each of these four periods are examined from the perspective of Humboldt's philosophy of

2 Daniel Fallon, "German Influences on American Education," in The German-American Encounter: Conflict and Cooperation between Two Cultures, ed. by Frank Trommler and Elliott Shore (New York: Berghahn Books, 2002), 85.

(C) 2018 F.P.A. Demeterio III and Roland Theuas DS. Pada

https://www.kritike.org/journal/issue 23/demeterio\&pada december2018.pdf ISSN 1908-7330

(c) $)$ BY-NC-ND 
education as well as its American translation. These documents are mentioned in the respective subsections under the third section of this paper. As a disclaimer for this study, our scope of analysis of UP's attempt to adopt the American translation of Humboldt's is based on archival documents to support our main arguments. Our study will not cover other factors such as the political, social, and other areas that are not covered in the archival documents of the University of the Philippines.

The insights that are culled by this paper can be helpful in the research planning and management of not only the country's nine research universities but also of the other Philippine universities that aim to boost their research productivities and/or move towards the Humboldtian model, or any other current dominant model, of the research university. With the looming ASEAN integration, a self-respecting Philippine higher educational institution has actually very little option left but to beef up its research capacity in order to compete with the real research universities within the ASEAN region.

The Commission on Higher Education's Memorandum Order 46, Series of 2012, is adding to this pressure. Among other things, this memorandum order intends to classify the existing Philippine higher educational institutions into professional institutions, colleges, or universities. Research is one of the bottlenecks for current universities to maintain their university classification or for current colleges to move up to the status of a university.

A literature search on Philippine research universities made through Google Scholar in April 2017 generated no relevant material. Hence, this paper could be the first published material that problematizes the research university in the Philippine setting. This paper also provides some preliminary groundwork for the succeeding efforts in formulating models of the research university that could be suitable to Philippine conditions.

\section{Humboldt's Philosophy of Education}

\section{Intellectual Biography and Social Context}

Humboldt was born in Potsdam in 1767. He started his higher education at the Prussian University in Frankfurt an der Oder but transferred to Gottingen University and studied jurisprudence, philology, natural sciences, and philosophy, particularly the one of Immanuel Kant. ${ }^{3}$ After finishing his studies in 1790 he went to Berlin to work in the Prussian

${ }^{3}$ Hermann Klencke and Gustav Schlesier, Lives of the Brothers Humboldt, Alexander and William (London: Ingram, Cooke, and Company, 1852), 253.

(c) 2018 F.P.A. Demeterio III and Roland Theuas DS. Pada https://www.kritike.org/journal/issue 23/demeterio\&pada december2018.pdf ISSN 1908-7330 


\section{A HUMBOLDTIAN CRITIQUE}

government. But only one year in civil service, he resigned, went to Jena, married, and stayed in that city up to 1797. At the University of Jena, he interacted with the romantic thinkers Johann Gottlieb Fichte, the brothers Friedrich and August Wilhelm Schlegel, Johann Wolfgang von Goethe, and Friedrich Schiller. ${ }^{4}$ From 1797 to 1801, Humboldt and his family stayed in Paris. It was during this period where his linguistic turn happened, fueled by his curiosity with the Basque language. He even went to Spain in order to study this language in its natural setting. From 1803 to 1808, Humboldt was back in the Prussian civil service, working as envoy to the Vatican. In Rome, he studied some native American languages.

From 1808 to 1810, Humboldt was back in Berlin to work under the Minister of the Interior as head of the ecclesiastical and education section. ${ }^{5}$ It was during the short period of work in the Prussian capital when he effected the so-called Humboldtian revolution in education by founding the University of Berlin. Without seeing the inauguration of the said university, Humboldt was sent to Vienna as the Prussian ambassador to Austria. ${ }^{6}$ There, he continued his linguistic studies. Around 1815, he was then reassigned as the Prussian representative to the German Confederation in Frankfurt am Main and was soon transferred to London as the Prussian ambassador to England. In 1819, he was back to Berlin to assist the Ministry of the Interior in drafting a new constitution for Prussia. However, in the same year, he was dismissed from the civil service due to some key disagreements with his superiors. He stayed near Berlin and spent his remaining time and energy for his scholarly works. He died in 1835 at the age of 67.

With Humboldt's very swift implementation of his educational revolution, one cannot help but wonder how he managed to effectuate this feat in such a short time. He was, of course, addressing some concrete and historical conditions that begged for a much-needed reformation of the Prussian educational system. The most salient among these concrete and historical conditions were: 1) Prussians who were defeated and humiliated by France and Napoleon Bonaparte and who were therefore clamoring for sociopolitical and cultural reforms; ${ }^{7}$ 2) a mercantilist orientation of pursuing research in the German universities, where such institutions pressure their professors to do research in order to increase the fame of their respective universities and contribute to the income of their respective cities and states; ${ }^{8}$

\footnotetext{
${ }^{4}$ Ibid., 287-299.

5 Ibid., 346.

${ }^{6}$ Ibid., 362.

${ }^{7}$ Ibid., 355.

${ }^{8}$ Chad Wellmon, Organizing Enlightenment: Information Overload and the Invention of the Modern Research University (Baltimore, MD: Johns Hopkins University Press, 2016), 222. See also Peter Josephson, "The Publication Mill: The Beginnings of Publication History as an Academic Merit in German Universities, 1750-1810," in The Humboldtian Tradition: Origins and Legacies, ed.
} 
3) professors who were financially lured to do research at the expense of relegating their teaching function as a task of lesser importance; $\left.{ }^{9} 4\right)$ the proliferation of printed books that had collectively been deemed as a less expensive replacement of professors as the main transmitters of knowledge; ${ }^{10}$ 5) an emerging concept of knowledge, from being something that is already made and complete and can be easily transmitted to being something that is always in the process of becoming and can never be completed and therefore cannot be easily transmitted;11 and 6) cities and states with diverse and unrelated learning institutions, such as primary schools, secondary schools, universities, specialized schools (such as the ones dealing with veterinary medicine, mining, trade, and the like), academies, anatomical theatres, libraries, museums, menageries, and botanical gardens. ${ }^{12}$

In addition to these concrete and historical conditions that pleaded for reforms, Humboldt also had his own sources, inspirations, models, and collaborators: 1) Gottingen University, which was one of the leading German universities at that time, where research was seriously pursued by its professors, and where Humboldt studied; ${ }^{13}$ 2) the University of Jena, which was also one of the leading German universities at that time, where academic freedom flourished, great intellectuals congregated, and where Humboldt lived nearby for a while; ${ }^{14} 3$ ) the philosopher Kant, who proposed that the faculty of philosophy should be at the heart of a university, since it is the faculty that can manage and critique knowledge, and who was one of the subjects of Humboldt's studies in Gottingen; ${ }^{15}$ and 4) the philosophers, man of letters, scientists, and philologists Fichte, Friedrich Schelling, Henrik Steffens, and Friedrich Schleiermacher, who already penned down some sketches on how to reform the German universities. ${ }^{16}$

One of the most amazing accomplishments that Humboldt had was to synthesize all his sources, inspirations, models, and collaborators' ideas as he addressed the concrete and historical conditions that begged for reforms.

by Peter Josephson, Thomas Karlsohn, and Johan Östling (Leiden: Brill Academic Publishers, 2014), 26-27.

${ }^{9}$ Josephson, “The Publication Mill," 28-29.

${ }^{10}$ Wellmon, Organizing Enlightenment, 225.

${ }^{11}$ Ibid., 220.

12 Klencke and Schlesier, Lives of the Brothers Humboldt, 362.

${ }^{13}$ Wellmon, Organizing Enlightenment, 211.

${ }^{14}$ Theodore Ziolkowski, "The Nineteenth-Century German University and German Idealism," in Reexamining Academic Freedom in Religiously Affiliated Universities: Transcending Orthodoxies, ed. by Kenneth Garcia (Cham: Palgrave Macmillan, 2016), 37.

${ }^{15}$ Sven-Eric Liedman, "In Search of Isis: General Education in Germany and Sweden," in The European and American University Since 1800: Historical and Sociological Essays, eds. Sheldon Rothblatt and Bjorn Wittrock (Cambridge: Cambridge University Press, 1993), 82.

16 Michael Peters, "On Narratives of Self-Formation and Education," in Psychosociological Issues in Human Resource Management, 3:2 (2015), 124-125.

(c) 2018 F.P.A. Demeterio III and Roland Theuas DS. Pada https://www.kritike.org/journal/issue 23/demeterio\&pada december2018.pdf ISSN 1908-7330 


\section{A HUMBOLDTIAN CRITIQUE}

He consolidated these in a master plan for the creation of the University of Berlin, as well as for the rationalization of the whole Prussian educational system, in that short window of time when he was able to convince the Prussian government to implement such master plan.

\section{The Foundation of the University of Berlin}

In 1808, Humboldt submitted to King Friedrich Wilhelm III of Prussia his master plan for the establishment of the University of Berlin. During the inauguration of the university, the Prussian king uttered the prophetic words: "the state must replace by intellectual powers what it has lost in material power." 17

Figure 1 schematically represents Humboldt's philosophical vision of the modern university. At the heart of the modern university, represented by a circle inside the triangle, is the dynamic and infinite conception of knowledge/science: "everything depends on preserving the principle of seeing science as something that has not been and can never be entirely found, and to constantly pursue it as such." 18 As already mentioned, one of the concrete and historical conditions that begged to be addressed by higher education was the emerging concept of knowledge and science from being something that is already made and complete and can be easily transmitted to being something that is always in the process of becoming and can never be completed and, therefore, cannot be easily transmitted. For Humboldt, teaching knowledge/science as something already made and complete is only good for the secondary school. ${ }^{19}$ It is a concession that he had to make to make secondary education capable of dispensing the broadest possible preparatory knowledge to its younger students. But in the modern university, knowledge/science should be taught as it really is: always in the process of becoming and never to be completed.

\footnotetext{
${ }^{17}$ Pieter Dhondt, "Humboldt in Belgium: Rhetoric on the German University Model," in The Humboldtian Tradition: Origins and Legacies, ed. by Peter Josephson, Thomas Karlsohn, and Johan Östling (Leiden: Brill Academic Publishers, 2014), 101.

18 Wilhelm Humboldt, "On the Internal and External Organization of the Higher Scientific Institutions in Berlin," in German History in Documents and Images, vol. 2, From Absolutism to Napoleon (1648-1815), ed. by William Hagen (Washington, D.C.: German Historical Institute, n.d.), http://germanhistorydocs.ghi-dc.org/sub_document.cfm?document_id=3642, 30 July 2017.

${ }^{19}$ Ibid., 1.

(c) 2018 F.P.A. Demeterio III and Roland Theuas DS. Pada

https://www.kritike.org/journal/issue 23/demeterio\&pada december2018.pdf

ISSN 1908-7330
}

(c) BY-NC-ND 


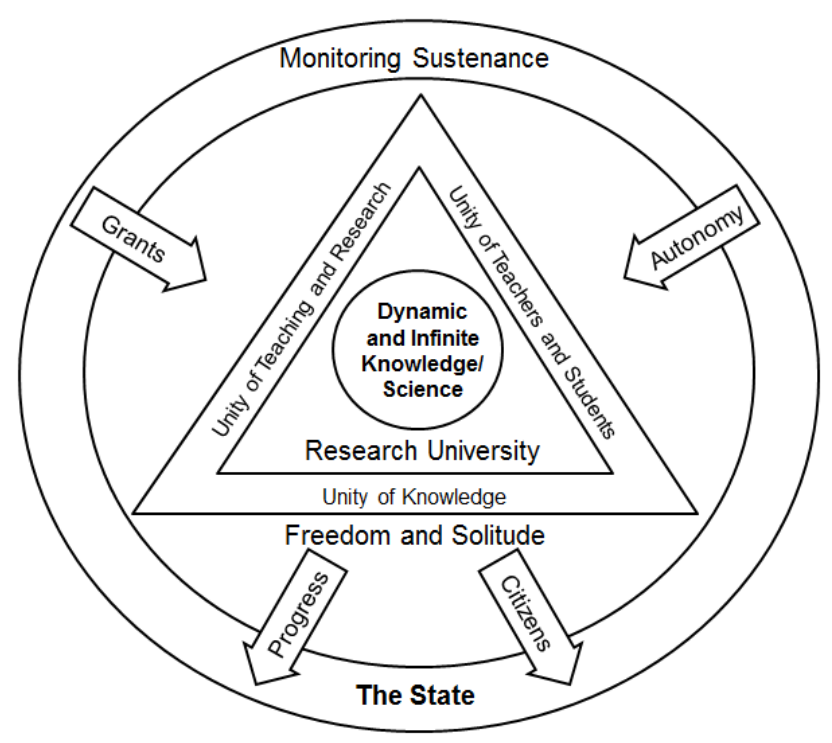

Figure 1: Schematic Representation of Humboldt's Philosophical Vision of the Modern University

For Humboldt, there are three unities in the modern university. ${ }^{20}$ The first of these unities is the unity of teaching and research, represented by the left side of the triangle. ${ }^{21}$ This unity implies that research is utilized as a method of teaching, and teaching is used as part of the research process. As also already mentioned, one of the concrete and historical conditions that required attention by higher education was the unfortunate situation where professors were financially lured to do research with the unintended consequence that they pursued research at the expense of relegating their teaching function as a task of lesser importance. This created the dichotomy between teaching and research in the traditional university. This dichotomy was banished forever in the modern research university in the sense that a good professor would always be a good researcher and a good teacher at the same time.

The second of the three unities mentioned by Humboldt is the unity of teachers and students, represented by the right side of the triangle. ${ }^{22}$ This unity implies that professors are expected to do research in collaboration with their students. The students need the experience and expertise of the professors for them to be introduced and trained in the process of research and learning. On the other hand, the professors also need the fresh ideas and out-of-the-box thinking and perspective of the students, as well as their

\footnotetext{
${ }^{20}$ Susan Harris-Huemmert, Evaluating Evaluators: An Evaluation of Education in Germany (Wiesbaden: VS Verlag für Sozialwissenschaften, 2011), 30-31.

${ }^{21}$ Ibid., 31.

22 Ibid., 30. See also, Humboldt, “Internal and External Organization," 2.
} 


\section{A HUMBOLDTIAN CRITIQUE}

youthful energies and passions, to further and deepen their research and teaching functions. ${ }^{23}$

The third of the three unities mentioned by Humboldt is the unity of knowledge/science, represented by the lower side of the triangle. ${ }^{24}$ This unity implies that all the knowledge/sciences pursued and produced by the different faculties and departments within the university are expected to be noncontradictory with each other and will eventually form a coherent whole. ${ }^{25}$

Humboldt stipulated that freedom and solitude, represented by the circle that immediately contains the triangle of three unities, must prevail within the university. ${ }^{26}$ This freedom and solitude will provide an atmosphere that is conducive for the professors and students to go on with their unending quest for knowledge/science. Freedom inside the modern university is specifically articulated as the freedom to teach and do research on the part of the professor, and freedom to learn on the part of the students. The state, therefore, must give autonomy, represented by the upper right arrow in figure 1 , to the modern university. ${ }^{27}$ It must prevent the church from interfering in the affairs of the modern university. Humboldt observed that freedom could be under threat externally, as well as, internally. ${ }^{28} \mathrm{~A}$ similar case can be seen in the establishment of the Frankfurt School and the Institute of Social Research. Conceived by Felix Weil and funded by his father, Hermann Weil, the institute pursued, from the very beginning, an academic institution that is free from interference to pursue its goal of unrestricted social research and theoretical innovation. ${ }^{29}$

Since the modern research university is an expensive venture, the state, represented by the outermost concentric circle in figure 1, must be willing to shoulder its whole operation. ${ }^{30}$ To assure that this financial support will not deteriorate sooner or later into policy interference, Humboldt preferred that financial support is given as land grants, represented by the upper left arrow in figure 1, rather than annual budgetary allocation. ${ }^{31}$ The sufficient income from the land grants will allow the university to have short range and long range plans. Aside from the financial support, Humboldt

\footnotetext{
${ }^{23}$ Humboldt, "Internal and External Organization," 5.

${ }^{24}$ Harris-Huemmert, Evaluating Evaluators, 31.

${ }^{25}$ Ibid.

${ }^{26}$ Humboldt, "Internal and External Organization," 1.

${ }^{27}$ Ibid.

${ }^{28}$ Ibid., 3.

${ }^{29}$ Martin Jay, Dialectical Imagination: A History of the Frankfurt School and the Institute of Social Research 1923-1950 (London: Heinemann Educational Books, 1976), 5.

${ }^{30}$ John Hargrove Van de Graaff, The Politics of German University Reform, 1819-1979

${ }^{31}$ Ibid.
}

(New York: Columbia University, 1973), 36.

(c) 2018 F.P.A. Demeterio III and Roland Theuas DS. Pada

https://www.kritike.org/journal/issue 23/demeterio\&pada december2018.pdf

ISSN 1908-7330

(c) BY-NC-ND 
expects the state to also monitor the university to prevent its institutional structure from deteriorating through time. ${ }^{32}$ Humboldt is particularly concerned with the recruitment of professors. If the modern university is left alone to recruit its professors, it could easily engage in nepotism and favoritism, just like what happened to the traditional and medieval universities. ${ }^{33}$ Humboldt is particularly concerned as well with the possibility that the university itself, or its senior professors, will suppress the freedom of the other entities within the university. ${ }^{34}$

After all the trouble of putting up the modern research university, providing it with autonomy and land grants, as well as monitoring its continued institutional integrity, the state will finally reap its gains and rewards. The modern university provides the state with knowledge/science that it needs to fuel its socio-economic and cultural progress, represented by the lower left arrow in figure 1.35 The modern university also provides the state with superior and intelligent citizens, represented by the lower right arrow in figure 1, who will work for the state's progress and development. ${ }^{36}$ Humboldt emphasized that the modern university and the state may disagree on some short-term issues, but in the end, the goals of the state and the goals of the university are one and the same: progress and development. ${ }^{37}$ This could be the fourth unity in the Humboldtian university. Humboldt believes that the research/education received by the students in the modern university would eventually provide them with the formation/cultivation (Bildung) that they will need as cultured and dedicated citizens of the state: "for only the science that comes from the inside and can be implanted into the inside also reshapes the character, and the state, just as humanity is not concerned with knowledge and talk, but with character and action." 38

\section{Rationalization of the Prussian Educational System}

Humboldt did not only focus his philosophy of education on reforming the traditional and medieval university into a modern university. He also rationalized the diverse and unrelated learning institutions that were found in many German cities and states, specifically: the primary schools; secondary schools; universities; specialized schools that were providing educational trainings in veterinary medicine, mining, trade, agriculture, and

\footnotetext{
${ }^{32}$ Humboldt, "Internal and External Organization," 2.

${ }^{33}$ Ibid., 5.

${ }^{34}$ Ibid., 3.

35 Wellmon, Organizing Enlightenment, 226.

${ }^{36}$ Ibid., 217.

${ }^{37}$ Humboldt, "Internal and External Organization," 4.

${ }^{38}$ Ibid., 3.
}

(c) 2018 F.P.A. Demeterio III and Roland Theuas DS. Pada https://www.kritike.org/journal/issue 23/demeterio\&pada december2018.pdf ISSN 1908-7330 


\section{A HUMBOLDTIAN CRITIQUE}

others; academies, anatomical theatres, libraries, museums, menageries, and botanical gardens. ${ }^{39}$ Figure 2 represents how Humboldt rationalized and interlocked these various learning institutions into a single Prussian educational system.

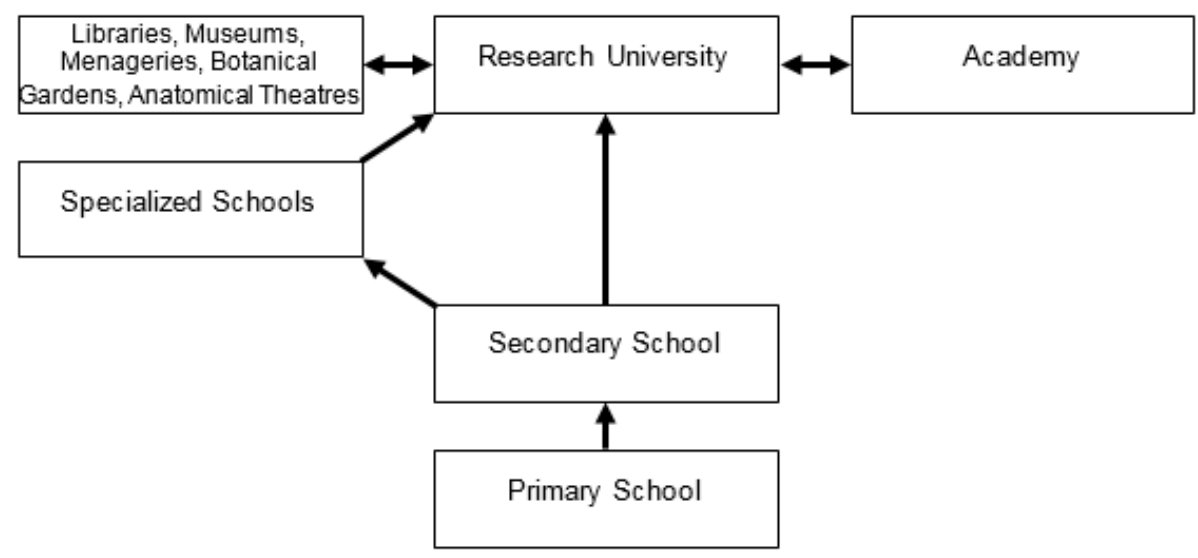

Figure 2: Humboldt's Interlocking of the Various Learning Institutions of Prussia into a Unified Prussian Educational System

Within the single Prussian educational system, curricular overlapping is avoided, and the lower or minor institutions of learning were made preparatory institutions or support institutions for the higher institutions of learning. Thus, the primary schools are expected to provide the fundamentals of learning that is necessary for the secondary schools. The secondary schools, in turn, provide broad general knowledge/science in preparation for the specialized fields in the specialized schools or the modern university. In the secondary schools, knowledge/science can remain as traditionally conceived: made and complete. ${ }^{40}$ Liberal education also happens in secondary schools. This will free a lot of time for the specialized knowledge/sciences in specialized schools and the modern university. Secondary education is very important for Humboldt to the point that he stipulated that only individuals who had university training should be allowed to teach in the secondary schools.

The specialized schools may be absorbed by the modern university. If it remains independent from the modern university, it can only provide training for specific skills (Erziehung) and not the superior

\footnotetext{
${ }^{39}$ Van de Graaff, The Politics of German University Reform, 30-31.

${ }^{40}$ Humboldt, "Internal and External Organization," 1.
} 
formation/cultivation (Bildung) provided by the modern university. ${ }^{41}$ The libraries, museums, anatomical theatres, menageries, and botanical gardens were brought closer to the university as additional venues for learning and research for both the professors and students, although these remained to be in the control of the state. ${ }^{42}$ The academy, previously the site of serious research, was also brought closer to the university. Humboldt believed that eventually, the modern university will eclipse the significance of the royal academy in terms of doing research because research in the modern university is continuous and efficient since it uses the intellectual powers and passions of the professors, but more so, the intellectual powers and passions of the stream of students. ${ }^{43}$

\section{Overview of the Humboldtian Educational Revolution}

With Humboldt's creation of the modern university, or his reformation of the traditional and medieval university, as well as his rationalization of the previously diverse and unrelated learning institutions within the German cities and states, he was able to successfully address the concrete and historical conditions that begged for a much-needed reformation. The Prussian government responded to the clamor for sociopolitical and cultural reforms of the humiliated and defeated Prussians through the establishment of the modern university.

The mercantilist orientation of pursuing research in the German universities was supplanted with a nobler orientation for research. Hence, instead of simply pressuring the professors to do research to increase the fame of their respective universities and contribute to the income of their respective cities and states, research became a pedagogical method that in the end would provide formation/cultivation (Bildung) to the students and sociopolitical and cultural progress to the state.

The tension between the teaching and research functions of the professors that arose from the financial allure of research was erased with the unification of teaching and research in the modern university. Theoretically speaking, the proverbial good researcher but the bad teacher and the good teacher but bad researcher could no longer thrive in the modern university since research became the way of teaching and teaching became part of research. The fear among traditional and medieval universities, as well as among professors, that the proliferation of books would eventually become their less expensive replacements is dispelled in Humboldt's philosophy of education. Books can only transmit made and complete knowledge and can

\footnotetext{
${ }^{41}$ Wellmon, Organizing Enlightenment, 217.

${ }^{42}$ Klencke and Schlesier, Lives of the Brothers Humboldt, 362.

${ }^{43}$ Humboldt, "Internal and External Organization," 5.
}

(c) 2018 F.P.A. Demeterio III and Roland Theuas DS. Pada https://www.kritike.org/journal/issue 23/demeterio\&pada december2018.pdf ISSN 1908-7330 


\section{A HUMBOLDTIAN CRITIQUE}

never compete with the modern university and its professors' capacity to handle knowledge as something that is always in the process of becoming.

The emerging concept of knowledge as something that is always in the process of becoming and will never be complete was responded to by the modern university's unification of teaching and research. In the modern university, knowledge is no longer transmitted for the sake of transmission. Instead, knowledge is transmitted as seeds for the students to generate new knowledge. The more pressing preoccupation in the modern university is to transmit to the students the skill of generating new knowledge. The German cities and states' diverse and unrelated learning institutions were rationalized and interlocked by Humboldt into a much stronger and efficient Prussian educational system.

The University of Berlin became the model of the modern university or more specifically the modern research university. The universities of Breslau and Bonn were the first ones to be established/reestablished after this model in 1811 and 1818, respectively. The model of the German research university achieved its definitive form at around 1830s and started to spread to the other German-speaking territories. ${ }^{44}$ In the early half of that same century, this model started to extend to the northern, eastern, and southern of Europe. ${ }^{45}$ Beyond Europe, the two countries that seriously pursued the model of the German research university were the United States of America and Japan. ${ }^{46}$

\section{American Translation of The Humboldtian Philosophy of Education}

From 1850 to 1870, American academics learned about the educational revolution that happened in Germany. ${ }^{47}$ Thousands of them went to Germany to obtain their doctor's degrees in the famed German universities, such as those of Berlin, Heidelberg, Leipzig, and Göttingen. ${ }^{48}$ Of

\footnotetext{
${ }^{44}$ William Clark, Academic Charisma and the Origins of the Research University (Chicago: University of Chicago Press, 2006), 28.

45 Ibid., 28.

${ }^{46}$ Altbach, "The Past, Present, and Future of the Research University," 15.

${ }^{47}$ Fallon, "German Influences on American Education," 85.

${ }^{48}$ Frank Trommler, "Recovering the History of Germanics in the United States: An Exploration," in Teaching German in Twentieth-Century America, ed. by David Benseler, Craig Nickisch, and Cora Lee Nollendorfs (Madison, WI: University of Winconsin Press, 2001), 28. See also Cameron Fincher, The Influence of British and German Universities on the Historical Development of American Universities (Athens, Georgia: Institute of Higher Education, University of Georgia, 1996), 4.

(c) 2018 F.P.A. Demeterio III and Roland Theuas DS. Pada

https://www.kritike.org/journal/issue 23/demeterio\&pada december2018.pdf

ISSN 1908-7330

(cc) BY-NC-ND
} 
these thousands of American academics, about 5,000 specifically studied at the University of Berlin. ${ }^{49}$

From 1869 to 1909, Charles William Eliot, who studied at the Marburg University, served as the president of Harvard University and led its transition from Harvard College to the leading American research university. In 1876, the Johns Hopkins University opened under the leadership of Daniel Coit Gilman, who studied at the University of Berlin. Johns Hopkins University was explicitly modelled after the German research university and became the first modern university in America and the first to offer graduate studies. ${ }^{50}$ In 1885, the Stanford University was founded. Of its original 30 professors, half earned their degrees in Germany. Its original logo even bore a German motto: Luft der Freiheit weht (the wind of freedom blows). In 1887, the Clark University was established under the leadership of Granville Stanley Hall, who studied further at the University of Berlin. To focus on research, Clark University started as a purely graduate-level university. It, however, opened its undergraduate programs more than a decade after. In 1890, the University of Chicago was founded under the leadership of William Rainey Harper. The University of Chicago made the innovation of retaining its undergraduate program as an English style college while modelling its graduate program on the German research university.

The American rendition of the Humboldtian model of the research university was supported by three landmark laws: the Morrill Act of 1862, the Hatch Act of 1887, and the Smith-Lever Act of 1914. ${ }^{51}$ Justin Smith Morrill, Senator from the State of Vermont, was the one who introduced the bill that would later be known as the Morrill Act of 1862. The act was intended to create land-grant colleges for the purpose of teaching "such branches of learning as are related to agriculture and the mechanic arts" but "without excluding other scientific and classical studies and including military tactic" so as "to promote the liberal and practical education of the industrial classes in the several pursuits and professions in life." 52 William Henry Hatch, Congressman from the State of Missouri, was the chairman of the house committee on agriculture when the bill that would later be known as the Hatch Act of 1887 was introduced. The act intended to provide federal funding to the land-grant colleges for them to establish agricultural experiment stations. The act, although limited to agriculture and its allied disciplines, could be considered as the legislated marker of the emergence of the American research universities. Michael Hoke Smith, Senator from the State of Georgia, and Asbury Francis Lever, Congressman from South

\footnotetext{
${ }^{49}$ Fincher, Influence of British and German Universities, 4.

${ }^{50}$ Ibid., 10.

51 Ibid.

${ }^{52}$ Morrill Act of 1862, 7 U.S.C. $§ 304$ (1862).
}

(c) 2018 F.P.A. Demeterio III and Roland Theuas DS. Pada https://www.kritike.org/journal/issue 23/demeterio\&pada december2018.pdf ISSN 1908-7330 


\section{A HUMBOLDTIAN CRITIQUE}

Carolina, advocated for the bill that would later be known as the Smith-Lever Act of 1914. The act mandated the land-grant colleges and universities to conduct extension services to disseminate information about innovations in "agriculture, uses of solar energy with respect to agriculture, home economics, and rural energy, and to encourage the application of the same." 53 If in the Humboldtian model of the research university extension is more like a tacit concept that undergirds the unity of goals of the state and the university, in the American model this is something that is made explicit by a legislation.

Roger Geiger's book To Advance Knowledge: The Growth of American Research Universities, 1900-1940, made the assertions that the American model of the research university's emphasis on the natural sciences became apparent in the 1850s, while its pursuance of utilitarian objectives became apparent in the 1860s. ${ }^{54}$ Thus, the Morrill Act of 1862, the Hatch Act of 1887, and the Smith-Lever Act of 1914 are more like the culmination of some trends that were going on in American higher education as America tried to appropriate the German model of the research university.

In the end, this was how the Americans translated the Humboldtian research university: the model was predominantly applied to graduate education in selected universities, while the American undergraduate education retained its old British model. ${ }^{55}$ Hence, the American model of the research university is a composite of a 17th-century British undergraduate base that supports a 19th-century Humboldtian graduate education. ${ }^{56}$ To energize this expensive model, the American research universities counted on expensive tuition fees, government endowments, private endowments, and further government grants. The Humboldtian unities of teaching and research, and of teachers and students were retained at the graduate level. The Humboldtian unity of the goals of state and university was highlighted with the American stress on extension programs. However, the Humboldtian unity of knowledge, that reserved a special place for philosophy, was set aside by the American fascination with utilitarian goals.

\footnotetext{
53 Smith-Lever Act of 1914, 7 U.S.C § 341 (1914).

${ }^{54}$ Roger Geiger, To Advance Knowledge: The Growth of American Research Universities, 1900-1940 (New York: Oxford University Press, 1986), 9.

${ }^{55}$ Fallon, "German Influences on American Education," 83. See also, Clark, Academic Charisma and the Origins of the Research University, 28. See also Fincher, Influence of British and German Universities, 1.

${ }^{56}$ Fallon, "German Influences on American Education," 83. See also Clark, Academic Charisma and the Origins of the Research University, 28.

(c) 2018 F.P.A. Demeterio III and Roland Theuas DS. Pada https://www.kritike.org/journal/issue 23/demeterio\&pada december2018.pdf ISSN 1908-7330
}

(c) BY-NC-ND 


\section{Critique of the University of The Philippines}

At its foundational stage, at least some people in UP were aware of the German and American research universities. Firstly, UP had a number of American professors who studied in either German or American research universities, such as Hans Aron (University of Berlin), Charles Fuller Baker (Stanford University), George William Beattie (University of California), Oliver Frederick Bishop (Yale University), William Hutchins Boynton (Cornell University), William Henry Brown (Cornell University), Edwin Bingham Copeland (Stanford University and the University of HalleWittenberg), Lawrence Edmonds Griffin (Johns Hopkins University), Dean Spruill Fansler (Columbia University), Paul Casper Freer (University of Munich), Eustace Merchant (Cornell University), and Archibald Ward (Cornell University). Secondly, the German language was taught at the university, and at its Los Baños campus, two years of learning the language was a requirement in order for the agricultural students to access the scientific literature. This policy reveals the American fascination with the German research university. Thirdly, two early university presidents explicitly mentioned in their inaugural addresses that the German university is known for its emphasis on research. But is UP a research university worthy of the same title as its German and American counterparts?

As already implied in the introductory section of this paper, such question will be covered by first periodizing UP into 1) its American colonial phase (1908-1946), 2) its liberation phase (1946-1972), 3) its system phase (1972-2008), and 4) its transition phase into a research university (2008present).

\section{The University During the American Colonial Period}

As already mentioned, this period spanned from 1908, the foundation of UP, to 1946, the end of the American colonial rule in the Philippines. The length of this period is 38 years. The key documents that were analyzed under the American colonial period of UP are: 1) the 1908 University Charter, or the Philippine Legislature Act Number 1870; 2) the inaugural speech of University President Murray Bartlett of 1911;3) the inaugural speech of University President Ignacio Villamor of 1915; 4) the inaugural speech of University President Guy Potter Benton of 1921; 5) the inaugural speech of University President Rafael Palma of 1925; 6) the Monroe Commission Report, otherwise known as A Survey of the Educational System of the Philippine Islands by the Board of Educational Survey, Created under Acts 3162 and 3196 of the Philippine Legislature, of 1925; 7) Encarnacion Alzona's book $A$ History of Education in the Philippines, 1565-1930 of 1932; 8) the inaugural 


\section{A HUMBOLDTIAN CRITIQUE}

speech of University President Jorge Bocobo of 1934; and 9) the inaugural speech of University President Bienvenido Gonzalez of 1939.

The 1908 University Charter (Act No. 1870): The foundational legislation of UP does not mention research. It states that the purpose of the university is: "to provide advanced instruction in literature, philosophy, the sciences, and arts, and to give professional and technical training." 57 Research, however, is hinted very faintly in its order for the university to establish endowed chairs in the colleges, and for the other government departments to lend and detail equipment, supplies and personnel to the university when needed. ${ }^{58}$ As it is, the foundational legislation of UP talks about a teaching university and not a research university.

The 1911 Inaugural Speech of Bartlett: Murray Bartlett was president of the university from 1911 to 1915. Research for him is a way of enriching classroom instruction:

undoubtedly in this university, there must be room, time, and provision for research. It would not make for efficiency if the professors spent all his time in teaching. He must keep abreast and ahead of his subject. He must inspire and enliven his instruction with inspiration gained from his own investigation. Only so can the student catch the spirit of initiative that is so necessary for the efficient worker in any field. ${ }^{59}$

The president was talking about a teaching university that should be enriched with research. He maintained the dichotomy between teaching and research.

The 1915 Inaugural Speech of Villamor: Ignacio Villamor was president of the university from 1915 to 1920 . He talked about research as something necessary for the sociopolitical, economic, and cultural development of the Philippines: "we should search the bowels of the earth to unfold its hidden treasures. We should transform raw materials to increase their commercial value. Science, in its various aspects, renders almost unlimited the power of the human efforts." 60 But he is not very clear about how this task is to be accomplished by the professors and students. His

\footnotetext{
${ }^{57}$ Act No. 1870, Sec. 2 (1908).

${ }^{58}$ Ibid., Sec. 6(d) and Sec. 14.

${ }^{59}$ Murray Bartlett, "A University for the Filipino," in The Role and Mission of the University: Inaugural Addresses of the Presidents of the University of the Philippines, ed. Consuelo Fonacier (Quezon City: University of the Philippines Press, 1971), 8.

${ }^{60}$ Ignacio Villamor, "The University and the People," in The Role and Mission of the University: Inaugural Addresses of the Presidents of the University of the Philippines, 25.

(c) 2018 F.P.A. Demeterio III and Roland Theuas DS. Pada https://www.kritike.org/journal/issue 23/demeterio\&pada december2018.pdf ISSN 1908-7330
}

(cc) BY-NC-ND 
statement appears like a mere lip service to the significance of research in the university.

The 1921 Inaugural Speech of Benton: Guy Potter Benton was president of the university from 1921 to 1925 . He wanted to limit the number of students to a realistically manageable group to allow the university to pursue excellence with its limited annual allocation. Research for him is still a way of enriching classroom instruction:

the best university instruction comes from the professor fresh from his investigations in the laboratory, and the research scientist finds the best confirmation of his conclusions by their application with his students in the classroom or lecture hall. The university teacher, without research habit, is dead on his feet, and the scientific investigator who does not teach is usually an impractical theorist. ${ }^{61}$

The president was again talking about a teaching university that should be enriched with research. He also maintained the dichotomy between teaching and research.

The 1925 Inaugural Speech of Palma: Rafael Palma was president of the university from 1925 to 1933 . His inaugural speech has no clear discussion on research at the university. But in his problematization on how to finance the developments in the university, he mentioned about his desire to ask the federal government itself, in Washington, D.C., to extend the benefits of the Hatch Act of 1887, the Adams Act of 1906, and the Smith-Lever Act of 1914 to UP as a publicly-funded university under the American colonial rule. ${ }^{62}$ The Hatch Act of 1887 and the Smith-Lever Act of 1914 were already mentioned as two of the three landmark laws that supported the American translation of the Humboldtian model of the research university. The Adams Act of 1906 is another legislation intended to further increase the federal funding to landgrant colleges and universities. Palma's intention to lobby in Washington, D.C. revealed the tacit understanding that the American government simply did not consider UP as one of its land-grant research colleges/universities.

The 1925 Monroe Commission Report: The Philippine Legislature authorized a 23-member team of American and Filipino educators to review the then two-decade-old American education implanted on the Philippine

\footnotetext{
${ }^{61}$ Guy Potter Benton, "Objectives of the University," in The Role and Mission of the University: Inaugural Addresses of the Presidents of the University of the Philippines, 48-49.

${ }^{62}$ Rafael Palma, "Inaugural Address," in The Role and Mission of the University: Inaugural Addresses of the Presidents of the University of the Philippines, ed. Consuelo Fonacier (Quezon City: University of the Philippines Press, 1971), 72.
}

(C) 2018 F.P.A. Demeterio III and Roland Theuas DS. Pada https://www.kritike.org/journal/issue 23/demeterio\&pada december2018.pdf ISSN 1908-7330 


\section{A HUMBOLDTIAN CRITIQUE}

soil. The head of the team was Paul Monroe, who at that time was the director of the International Institute of Teacher's College at the Columbia University. The eighth chapter of the team's report zeroed in on UP. This chapter is not only longer than any of the first five documents examined by this subsection, but its tone is also incisive and diagnostic instead of being futuristic and laudatory like the said first five documents.

The chapter mentions not less than ten phenomena that hindered the university's transition to a research university or at least its desire to strengthen its research capability. First is the incongruence between the Filipino-Spanish educational system and the American educational system. In the Filipino-Spanish educational system, the freshmen are younger than their American counterparts, and these younger freshmen were first required to take a two-year bachelor's degree program before they proceed to another two-year professional degree program. It was only in 1919 that UP discarded the two-year bachelor's degree training so that the freshmen can go directly to their professional degree training just like their American counterparts. ${ }^{63}$ However, UP was not able to address the fact that its freshmen were younger and therefore less intellectually mature than their American counterparts.

Second is the language gap between the English medium of the university and the Filipinos who were just recently trying to master the language of their new colonizers. ${ }^{64}$ If teaching these Filipino students was already a big challenge for the academic staff, it would be much more challenging to do meaningful research with them. The third is the meddling of the Filipino politicians with the governance of the university. The report emphasized: "in all political affairs and in all activities of the politicians, considerations of expediency and policy and even of partisanship and propaganda are bound to be influential." 65 Fourth is the rapid increase of the university's student population, which from 1911 to 1924 registered an average annual increase of $13.53 \% .{ }^{66}$ The report explained: "Unfortunately, when we come to the section entitled Income of the University, we shall see that the support necessary for efficient administration has not by any means kept with an increase in numbers." ${ }^{67}$ A rapidly growing university that can hardly support itself as a teaching university could not be expected to transition into a much more expensive research university.

\footnotetext{
${ }^{63}$ Paul Monroe, A Survey of the Educational System of the Philippine Islands by the Board of Educational Survey, Created under Acts 3162 and 3196 of the Philippine Legislature (Manila: Bureau of Printing, 1925), 610.

${ }^{64}$ Ibid.

65 Ibid., 613.

${ }^{66}$ Ibid., 616.

${ }^{67}$ Ibid., 617.

(c) 2018 F.P.A. Demeterio III and Roland Theuas DS. Pada https://www.kritike.org/journal/issue 23/demeterio\&pada december2018.pdf ISSN 1908-7330
}

(c) BY-NC-ND 
Fifth is the failure of the Philippine Legislature to petition the federal government to make UP a beneficiary of the Hatch Act of 1887, the Adams Act of 1906, and the Smith-Lever Act of 1914. ${ }^{68}$ The data gathering interviews of Monroe's team with the officials of UP could be what triggered Palma to articulate his desire to bring such petition to Washington, D.C. Sixth is the deplorable condition of the collection of the university library which the report labelled as "the weakest division of the University." 69 In the age prior to the internet, it is not right to expect quality research from both faculty and students when the library is below standard. Seventh is the heavy workload of the faculty members and their lack of resources that prevented them from producing quality output despite the abundance of potential research problems and topics in the Philippine setting and despite the talents and capacities of these faculty members. ${ }^{70}$ Eighth is the archipelagic geography of the Philippines and the average literacy and scientific readiness of the Filipinos that would make the extension more challenging. ${ }^{71}$

Ninth is the unreadiness of the university to establish a researchbased graduate school. The report explained: "no department of a university is costlier than a graduate school requiring as it does special laboratory and library facilities and personnel of unusual attainments - another matter of expense. UP is a young institution whose foundations need strengthening. Its limited resources should be concentrated on improving the work in which it is already engaged." 72 The tenth is the age demography of the faculty members, where $82 \%$ is below 40 years old. The report stated: "the comparative youth of the teaching staff is no doubt also the explanation of its relative sterility in scholarly productivity." 73 Added to this phenomenon that a huge portion of faculty members are part-time lecturers and teaching assistants. ${ }^{74}$ This demographic flaw is an outcome of the rapid increase of student numbers.

The 1932 History of Philippine Education of Alzona: The sixteenth chapter of Alzona's book focused on UP. This chapter is also longer than any of the inaugural speeches of the University Presidents, although its tone is not as incisive and diagnostic, compared to the Monroe Commission Report. The chapter mentions not less than five phenomena that have bearing to research. First is the explication that research has become part of the faculty

\footnotetext{
${ }^{68}$ Ibid., 629.

${ }^{69}$ Ibid., 643.

${ }^{70}$ Ibid., $645-645$.

${ }^{71}$ Ibid., 645 .

72 Ibid.

${ }^{73}$ Ibid., 654 .

${ }^{74}$ Ibid., 655
}

(c) 2018 F.P.A. Demeterio III and Roland Theuas DS. Pada https://www.kritike.org/journal/issue 23/demeterio\&pada december2018.pdf ISSN 1908-7330 


\section{A HUMBOLDTIAN CRITIQUE}

members' promotion in rank. ${ }^{75}$ Second is a reduction of the faculty members' teaching loads to 15 hours a week, which according to Alzona is "the current. . p practice in many American state universities." 76 The third is the decrease in the percentage of average annual increase in student numbers. If the Monroe Commission Report recorded an average annual increase of $13.53 \%$ from 1911 to 1924, Alzona only recorded an average annual increase of $4.87 \%$ from 1924 to $1930 .{ }^{77}$ But the trend was still about the annual increase in student numbers.

Fourth is the provision of a ten thousand-hectare land grant to UP, through the efforts of Palma and through the Act No. 3608 of 1930.78 However, the grant was not only two thousand hectares smaller than what was guaranteed by the Morrill Act of 1862, but it was also not meant to be sold but to be managed agriculturally or commercially. ${ }^{79}$ The Morrill Act of 1862 specified that the land should be sold and the proceeds are made into a trust fund for a given state college/university. ${ }^{80}$ Hence the land grant given to UP was not only smaller for a university that was growing bigger and bigger, but also created another managerial and entrepreneurial concern for the university. Nevertheless, Alzona saw it as "a beginning...to endow the university with a dependable source of income." ${ }^{81}$ Fifth is the reference to a partially centralized graduate programs for the Colleges of Liberal Arts, Education, and Agriculture, where such program remained non-researchbased and limited still to the masteral level. ${ }^{82}$ As a whole, although the sixteenth chapter of Alzona's book talks about favorable developments that strengthen research at UP, it also implies that the university was still unable to transition into a research university.

The 1934 Inaugural Speech of Bocobo: Dr. Jorge Bocobo was president of the university from 1934 to 1939. In his inaugural speech, he lamented the $45 \%$ reduction of the 1935 university budget with reference to the 1931 university budget. ${ }^{83} \mathrm{He}$ mentioned that such reduction put on hold some 500 research projects, of which $65 \%$ were supposed to be done in the College of Agriculture. ${ }^{84}$ With regard to the necessity of pursuing research,

75 Encarnacion Alzona, A History of Education in the Philippines, 1565-1930 (Manila: University of the Philippines Press, 1932), 280.

76 Ibid., 281-282.

77 Ibid., p.286.

${ }^{78}$ Ibid., p.292.

${ }^{79}$ Act No. 3608, Sec.3 (1930).

${ }^{80}$ Morrill Act of 1862, 7 U.S.C. $\S 304$ (1862).

${ }^{81}$ Ibid.

82 Ibid., 327-328.

83 Jorge Bocobo, "Presidential Inaugural Address," in The Role and Mission of the University: Inaugural Addresses of the Presidents of the University of the Philippines, 102.

${ }^{84}$ Ibid., 103-104.

(c) 2018 F.P.A. Demeterio III and Roland Theuas DS. Pada

https://www.kritike.org/journal/issue 23/demeterio\&pada december2018.pdf ISSN 1908-7330

(c) $)$ BY-NC-ND 
he stated: "the teaching for scientific agriculture in the Philippines must rely chiefly on our own researches because of the peculiarity of local conditions. Though to a less degree, the same problem confronts medicine, law, business, education, engineering, and the social sciences in these islands." 85 For Bocobo, research may be a means of developing the Philippine society, but in the context of education, it remained as a tool of scrounging suitable teaching materials.

The 1939 Inaugural Speech of Gonzalez: Dr. Bienvenido Gonzalez, an agricultural scientist trained in Johns Hopkins University, was president of the university from 1939 to 1943, and from 1945 to 1951. From 1943 to 1945, the president was Dr. Antonio Sison. These two are considered as the wartime presidents of the university. In his first inaugural address, Gonzalez admitted that research is something "that has suffered from relative neglect." $86 \mathrm{He}$ argued that research in the university is something necessary for the Philippine society: "For our own (university) to carve for herself a position of leadership among our people, she must take upon herself the task of studying our problems systematically and as far back as necessary so that with proper understanding, and in the light of experience, solutions may be worked out." ${ }^{87}$ Gonzalez, however, is silent about the interrelationship between teaching and research.

Summation: The story of UP during its American colonial period appears to be a story of a teaching university that had some aspirations to transition into a research university in its graduate level or at least strengthen the research capacity of its faculty members. It was a university that was controlled by the Philippine Legislature, and it was obliged to take in an increasing number of students that was way beyond what its annual allocations can reasonably accommodate. When it was constructively critiqued by the Monroe Commission it appeared to have responded well, such that in the early 1930s Alzona was able to record remarkable gains towards the strengthening of faculty research. But during the presidencies of Bocobo and Gonzalez, such gains appeared to be eclipsed by the great depression that impacted the Philippines in the 1930s and 1940s. The university remained a teaching university with a huge undergraduate population and a small body of master's level, non-research-based graduate students. It also appears that in order to respond to the great depression, the large segment of the middle class employed in the civil service and schools

\footnotetext{
85 Ibid., 105

${ }^{86}$ Bienvenido Gonzalez, "A University for the Philippines," in The Role and Mission of the University: Inaugural Addresses of the Presidents of the University of the Philippines, 129.

${ }^{87}$ Ibid., 121.
}

(c) 2018 F.P.A. Demeterio III and Roland Theuas DS. Pada https://www.kritike.org/journal/issue 23/demeterio\&pada december2018.pdf ISSN 1908-7330 


\section{A HUMBOLDTIAN CRITIQUE}

had to experience a decline in promotions and funding. ${ }^{88}$ Furthermore, this decline led to the inability of new high school and college graduates to find employment, thus, the trend following this, lead to the influx of growth in the public teaching sector in 1937-1939. ${ }^{89}$ The American colonial period of UP was concluded with the devastation of the Manila and Los Baños campuses brought about by the Second World War.

(Continued in Part II)

Department of Filipino, De La Salle University, Philippines Department of Philosophy, University of Santo Tomas, Philippines

\section{References}

Abueva, Jose, Reinventing UP as the National University: Learning for Truth, Leadership, and Social Transformation (Quezon City: University of the Philippines, 2008).

Act No. 1870, An Act for the Purpose of Founding a University for the Philippine Islands, Giving It Corporate Existence, Providing for a Board of Regents, Defining the Board's Responsibilities and Duties, Providing Higher Professional Instruction, and for Other Purposes (1908).

Act No. 3608, An Act Endowing the University of the Philippines with Portions of Lands of the Public Domain for Additional Support and Maintenance, and for other Purposes (1930).

Adams Act of 1906, An Act to Provide for an Increased Annual Appropriation for Agricultural Experiment Stations and Regulating the Expenditure Thereof (1906).

Altbach, Philip, "The Past, Present, and Future of the Research University," in The Road to Academic Excellence: The Making of World-Class Research Universities, ed. by Philip Altbach and Jamil Salmi (Washington, D.C.: The World Bank, 2011).

Alzona, Encarnacion, A History of Education in the Philippines, 1565-1930 (Manila: University of the Philippines Press, 1932).

Bartlett, Murray, "A University for the Filipino," in The Role and Mission of the University: Inaugural Addresses of the Presidents of the University of the Philippines, ed. by Consuelo Fonacier (Quezon City: University of the Philippines Press, 1971).

Bauzon, Leslie, “Angara's Tough Minded Leadership: The Diamond Jubilee Highlighted by Reform of the University System," in University of the

88 Daniel F. Doeppers, "Metropolitan Manila in the Great Depression: Crisis for Whom?" The Journal of Asian Studies, 50:3 (August 1991), 516.

${ }^{89}$ Ibid., 517.

(c) 2018 F.P.A. Demeterio III and Roland Theuas DS. Pada

https://www.kritike.org/journal/issue 23/demeterio\&pada december2018.pdf

ISSN 1908-7330

(c) $\mathrm{BY}-\mathrm{NC}-\mathrm{ND}$ 
Philippines: The First 75 Years (1908-1983), ed. by Oscar Alfonso (Quezon City: University of the Philippines, 1985).

Benton, Guy Potter, "Objectives of the University," in The Role and Mission of the University: Inaugural Addresses of the Presidents of the University of the Philippines, ed. by Consuelo Fonacier (Quezon City: University of the Philippines Press, 1971).

Bocobo, Jorge, "Presidential Inaugural Address," in The Role and Mission of the University: Inaugural Addresses of the Presidents of the University of the Philippines, ed. by Consuelo Fonacier (Quezon City: University of the Philippines Press, 1971).

Carson, Arthur, Higher Education in the Philippines (Washington, D.C.: United States Printing Office, 1961).

Clark, William, Academic Charisma and the Origins of the Research University (Chicago: University of Chicago Press, 2006).

Concepcion, Danilo, "Redefining the Culture of the University of the Philippines: Honor and Excellence with Compassion," (Diliman, Quezon City: Office of the Secretary of the University, 2016), http://osu.up.edu.ph/wp-content/uploads/2016/09/VISION PROF.DANILO-L.-CONCEPCION.pdf, 30 July 2017.

Dhondt, Pieter, "Humboldt in Belgium: Rhetoric on the German University Model," The Humboldtian Tradition: Origins and Legacies, ed. by Peter Josephson, Thomas Karlsohn, and Johan Östling (Leiden: Brill Academic Publishers, 2014).

Doeppers, Daniel F, "Metropolitan Manila in the Great Depression: Crisis for Whom?" The Journal of Asian Studies, 50:3 (August 1991).

Dyde, Walter, A Report on Graduate Education in the Philippines (Quezon City: Graduate College of Education, University of the Philippines, 1962).

Education Division, USOM to the Philippines, A Report of a Decade of U.S. Assistance to Public Education in the Philippines: The 10th Milestone Manila 1962 (Manila: USOM to the Philippines, Agency for Internationl Development, 1961).

Endriga, Jose, "Corpuz and Soriano's Bifocal Administrations: Toward a Realignment of the Academe to National Realities under a Crisis Government," in University of the Philippines: The First 75 Years (19081983), ed. by Oscar Alfonso (Quezon City: University of the Philippines, 1985).

Evangelista, Oscar, "Lopez's Beleaguered Tenure: Barricades on Campus at the Peak of Student Discontent," University of the Philippines: The First 75 Years (1908-1983), ed. by Oscar Alfonso (Quezon City: University of the Philippines, 1985).

Fallon, Daniel, "German Influences on American Education," in The GermanAmerican Encounter: Conflict and Cooperation Between Two Cultures, ed.

(C) 2018 F.P.A. Demeterio III and Roland Theuas DS. Pada https://www.kritike.org/journal/issue 23/demeterio\&pada december2018.pdf ISSN 1908-7330 
104 A HUMBOLDTIAN CRITIQUE

by Frank Trommler \& Elliott Shore (New York: Berghahn Books, 2002).

Fincher, Cameron, The Influence of British and German Universities on the Historical Development of American Universities (Athens, Georgia: Institute of Higher Education, University of Georgia, 1996).

Fores-Ganzon, Guadalupe, "Research," in Reappraisal and Rededication: Papers and Proceedings, 1966 UP Faculty Conference, ed. by Hernando Abaya. (Quezon City: University of the Philippines, 1966).

Geiger, Roger, To Advance Knowledge: The Growth of American Research Universities, 1900-1940 (New York: Oxford University Press, 1986).

Gonzalez, Bienvenido, "A University for the Philippines," in The Role and Mission of the University: Inaugural Addresses of the Presidents of the University of the Philippines, ed. by Consuelo Fonacier (Quezon City: University of the Philippines Press, 1971).

Harris-Huemmert, Susan, Evaluating Evaluators: An Evaluation of Education in Germany (Wiesbaden: VS Verlag für Sozialwissenschaften, 2011).

Hatch Act of 1887, An Act to Establish Agricultural Experiment Stations in Connection with the Colleges Established in the Several States under the Provisions of an Act Approved July Second, Eighteen Hundred and Sixty-Two, and of the Acts Supplementary Thereto, 7 U.S.C. $\S$ 361 (1887).

von Humboldt, Wilhelm. "On the Internal and External Organization of the Higher Scientific Institutions in Berlin," in German History in Documents and Images, Vol. 1, From Absolutism to Napoleon (16481815), ed. by William Hagen (Washington, D.C.: German Historical Institute, n.d.), http://germanhistorydocs.ghidc.org/sub document.cfm?document id=3642, 30 July 2017.

Javier, Emil, "U.P. in the Service of the Nation: Recapturing the Sense of National Purpose," in The Investiture of Dr. Emil Q. Javier as Sixteenth President of the University of the Philippines (Quezon City: University of the Philippines, 1994).

Jay, Martin, Dialectical Imagination: A History of the Frankfurt School and the Institute of Social Research 1923-1950 (London: Heinemann Educational Books, 1976).

Josephson, Peter, "The Publication Mill: The Beginnings of Publication History as an Academic Merit in German Universities, 1750-1810," in The Humboldtian Tradition: Origins and Legacies, ed. by Peter Josephson, Thomas Karlsohn, and Johan Östling (Leiden: Brill Academic Publishers, 2014).

Klencke, Hermann, and Gustav Schlesier, Lives of the Brothers Humboldt, Alexander and William (London: Ingram, Cooke and Company, 1852).

(c) 2018 F.P.A. Demeterio III and Roland Theuas DS. Pada

https://www.kritike.org/journal/issue 23/demeterio\&pada december2018.pdf

ISSN 1908-7330

(cc) BY-NC-ND 
Liedman, Sven-Eric, "In Search of Isis: General Education in Germany and Sweden," in The European and American University Since 1800: Historical and Sociological Essays, ed. by Sheldon Rothblatt and Bjorn Wittrock (Cambridge: Cambridge University Press, 1993).

Lopez, Salvador, "The University as Social Critic and Agent of Change," in The Role and Mission of the University: Inaugural Addresses of the Presidents of the University of the Philippines, ed. by Consuelo Fonacier (Quezon City: University of the Philippines Press, 1971).

Monroe, Paul, A Survey of the Educational System of the Philippine Islands by the Board of Educational Survey, Created under Acts 3162 and 3196 of the Philippine Legislature (Manila: Bureau of Printing, 1925).

Morales, Alfredo, "Our Goal of Quality Education," in Reappraisal and Rededication: Papers and Proceedings, 1966 UP Faculty Conference, ed. by Hernando Abaya (Quezon City: University of the Philippines, 1966).

Morgan, Keith, "Where is von Humboldt's University Now?" in Research in Higher Education-Daigaku Ronshu, 42 (March 2011).

Morrill Act of 1862, An Act Donating Public Lands to the Several States and Territories which May Provide Colleges for the Benefit of Agriculture and the Mechanic Arts, 7 U.S.C. § 304-309 (1862).

Nemenzo, Francisco, UP into the 21st Century and other Essays (Quezon City: University of the Philippines Press, 2000).

Office of the President of the University of the Philippines, University of the Philippines Strategic Plan 2011-2017 (Quezon City: University of the Philippines, 2012).

Office of the Vice President for Academic Affairs of the University of the Philippines, Shaping our Institutional Future: A Statement on Faculty Tenure, Rank and Promotion (Quezon City: University of the Philippines, 2004).

Office of the Vice President for Academic Affairs of the University of the Philippines, A University of the Philippines Research Guidebook (Quezon City: University of the Philippines, 2015).

Palma, Rafael, "Inaugural Address," in The Role and Mission of the University: Inaugural Addresses of the Presidents of the University of the Philippines, ed. by Consuelo Fonacier (Quezon City: University of the Philippines Press, 1971).

Pascual, Alfredo, "President Pascual's Turnover Speech," in UP Newsletter: The University of the Philippines Newspaper, 32:2 (February 2011).

Peters, Michael. "On Narratives of Self-Formation and Education," Psychosociological Issues in Human Resource Management, 3:2 (2015).

Presidential Decree No. 58, Constituting the University of the Philippines at Los Banos, Granting It Full and Complete Autonomy, and Amending the Charter of the University of the Philippines (1972).

(C) 2018 F.P.A. Demeterio III and Roland Theuas DS. Pada

https://www.kritike.org/journal/issue 23/demeterio\&pada december2018.pdf

ISSN 1908-7330 
106 A HUMBOLDTIAN CRITIQUE

"QS University Rankings: Asia 2016," in QS Top Universities, https://www.topuniversities.com/university-rankings/asianuniversity-rankings/2016, 14 August 2017.

Republic Act 9500, An Act to Strengthen the University of the Philippines as the National University (2008).

Revised Code of the University of the Philippines (Diliman, Quezon City: U.P. Law Center, 1975), http://osu.up.edu.ph/wpcontent/uploads/2014/05/UNIVERSITY-CODE-1961 1.pdf, 30 July 2017.

Roman, Emerlinda, "The University of the Philippines: A National University in the 21st Century," in The University of the Philippines Gazette, 36:3 (July-September 2005).

Romulo, Carlos, "Toward the Best University for the Filipino," in The Role and Mission of the University: Inaugural Addresses of the Presidents of the University of the Philippines, ed. by Consuelo Fonacier (Quezon City: University of the Philippines Press, 1971).

Sinco, Vicente, "The University of the Philippines and its Mission," in The Role and Mission of the University: Inaugural Addresses of the Presidents of the University of the Philippines, ed. by Consuelo Fonacier (Quezon City: University of the Philippines Press, 1971).

Smith-Lever Act of 1914, An Act to Provide for Cooperative Agricultural Extension Work between the Agricultural Colleges in Several States Receiving the Benefits of an Act of Congress approved July Second, Eighteen Hundred and Sixty-Two, and of Acts Supplementary Thereto, and the United States Department of Agriculture, 7 U.S.C $\S$ 341-349 (1914).

Tan, Vidal, "The Role of our State University," in The Role and Mission of the University: Inaugural Addresses of the Presidents of the University of the Philippines. ed. by Consuelo Fonacier (Quezon City: University of the Philippines Press, 1971).

Trommler, Frank, "Recovering the History of Germanics in the United States: an Exploration," in Teaching German in Twentieth-Century America, ed. by David Benseler, Craig Nickisch, and Cora Lee Nollendorfs (Madison, WI: University of Wisconsin Press, 2001).

United States Office of Mission to the Philippines, The Tenth Milestone: A Report of a Decade of U.S. Assistance to Public Education in the Philippines, 1952-1962 (Manila: United States Office of Mission to the Philippines, Agency for International Development, 1962).

Valenzuela, Victor, "Graduate Education," in Reappraisal and Rededication: Papers and Proceedings, 1966 UP Faculty Conference, ed. by Hernando Abaya (Quezon City: University of the Philippines, 1966).

(c) 2018 F.P.A. Demeterio III and Roland Theuas DS. Pada https://www.kritike.org/journal/issue 23/demeterio\&pada december2018.pdf ISSN 1908-7330

(c) BY-NC-ND 
Van de Graaff, John Hargrove, The Politics of German University Reform, 18191979 (New York: Columbia University, 1973).

Villamor, Ignacio, "The University and the People," in The Role and Mission of the University: Inaugural Addresses of the Presidents of the University of the Philippines, ed. by Consuelo Fonacier (Quezon City: University of the Philippines Press, 1971).

Wellmon, Chad, Organizing Enlightenment: Information Overload and the Invention of the Modern Research University (Baltimore, MD: Johns Hopkins University Press, 2016).

Ziolkowski, Theodore, "The Nineteenth-Century German University and German Idealism," in Reexamining Academic Freedom in Religiously Affiliated Universities: Transcending Orthodoxies, ed. by Kenneth Garcia (Cham: Palgrave Macmillan, 2016). 